Article

\title{
Social Innovations for Sustainable Consumption and Their Perceived Sustainability Effects in Tehran
}

\author{
Samira Iran ${ }^{1, *(1)}$ and Martin Müller ${ }^{2, *}$ \\ 1 Department of Economic Education and Sustainable Consumption, Institute of Vocational Education \\ and Work Studies, Technische Universität Berlin, 10587 Berlin, Germany \\ 2 Institute of Sustainable Corporate Management, Ulm University, 89081 Ulm, Germany \\ * Correspondence: samira.iran@tu-berlin.de (S.I.); martin.mueller@uni-ulm.de (M.M.); \\ Tel.: +49-(0)-30-314-28770 (S.I.); +49-(0)-731-50-32350 (M.M.)
}

Received: 22 July 2020; Accepted: 14 September 2020; Published: 17 September 2020

\begin{abstract}
Against the backdrop of current sustainability problems, various social innovations for sustainable consumption are emerging across the globe. In order to explore the sustainability potentials of such initiatives, it is vital to understand (1) why consumers are accepting and joining these initiatives and (2) how they perceive the sustainability potentials of initiatives' offers. In order to correctly estimate the sustainability potential of the initiatives, one should consider possible negative sustainability impacts as well as rebound effects alongside all the positive sustainability effects. Moreover, studies on social innovations for sustainable consumption have mostly been conducted in the context of the Global North. This paper focuses on studying and understanding the current situation of social innovations for sustainable consumption and its sustainability potentials in Tehran, Iran. A qualitative explorative study was conducted using desk research as well as semi-structured in-depth interviews with Iranian consumers. The results of this study confirm the existence of growing supply and demand trends for such initiatives in Iran. Among the different initiatives, those that are copies of international companies or offering alternative mobility solutions seem to have more chances for diffusion, as consumers are more motivated to use their offers. The sample of this study believed that by joining these initiatives, they could contribute to achieving greater sustainability. However, the results of the interviews also show that the possible negative sustainability and rebound effects of their engagement in such initiatives were often neglected. Therefore, there is still a need not only for educating consumers about the overall sustainability potentials of these initiatives but also for exhibiting the sustainability impacts that their consumption behaviors regarding the use of initiatives' offers can have. This way, these initiatives can be more successful in terms of contributing to sustainability.
\end{abstract}

Keywords: social innovation; sustainable consumption; sustainability; rebound effects; Iran

\section{Introduction}

Conventional patterns of production and consumption of goods and services are causing irreversible environmental and socio-economic problems all around the world. Social innovations have been claimed to be a possible means of sustainable development. Proponents of social innovations aim to offer solutions that go beyond economic and technological fixes for sustainability problems; they also emphasize value creation in their efforts [1,2]. Grimm and his colleagues [3] (437) mention, "While societal development in the nineteenth and twentieth centuries was driven by technological progress and economic dogmas, the twenty-first century must give rise to social innovation to encourage societal and systemic changes". The insufficiency of the traditional welfare systems in responding to the growing and diverse demands of societies attracted the attention of policymakers for social 
innovations [4]. Therefore, for instance, the European Union puts "great hopes in social innovation to design and implement creative ways of meeting social needs and to build cohesive and sustainable societies" [3] (437). There have been many attempts to define the term "social innovation" [5-7]. In this paper, the authors apply the definition offered by Jaeger-Erben and her colleagues [6] (785) and consider social innovations "as alternative practices or new variations of practices which differ substantially from established or mainstream routines". According to their definition, "innovative practices do not necessarily need to be complete novelties", but the social innovations should imply structural changes [6] (785). Taking that into consideration, social innovations for sustainable consumption (SISC) are here defined as to be those initiatives that not only have innovative characteristics and offer alternative solutions to mainstream practices, but also have at least some potentials for promoting greater sustainability when compared to current mainstream consumption practices. The phenomenon of SISC has been further highlighted as a powerful resource for tackling social and environmental challenges [8,9].

Research on SISC has been mostly conducted in developed countries, and there is still a lack of such research considering the Global South context [5]. SISC could be solutions for (at least) some of the current environmental and social issues of the Global South (e.g., air pollution and traffic congestion or social inequalities in a city such as Tehran $[10,11])$. Besides, some SISC examples can be observed in different country contexts (e.g., Couchsurfing). However, there are also many SISC that are developed and appropriated in specific cultural contexts (e.g., Mamanpaz in Iran). Such context-specific examples can not necessarily be found or explored in developed countries. Therefore, there is still a need for studying SISC and their sustainability potentials in the Global South context. This study focuses on the SISC examples in Tehran, the capital city of Iran, where a growing number of emerging SISC can be observed.

Social innovations and SISC are relatively new phenomena in Iran. There is, accordingly, a lack of research on these concepts in the Iranian context. This might be due to the fact that the term "social innovation" (and accordingly SISC) encompasses different organizational forms and approaches such as services initiated by enterprises or grassroot initiatives. However, even considering looking for literature regarding such specific concepts, a research gap could be observed. An exception is limited literature on the concept of start-up communities in Iran, which is not directly relevant for this study. Founders of social innovations in Iran are advertising their more eco-efficient offers and claim to be able to reduce the environmental impacts of consumption in Iran. However, not only these founders but also the consumers themselves are often unaware of (or willfully ignorant of) possible negative sustainability effects that could result from the provided services. In order to study SISC in Tehran, this paper initially undertook qualitative research on 40 cases of presumed SISC in this city, followed by 20 in-depth interviews that were conducted with young consumers. By applying qualitative research methods (desk-research and in-depth interviews by a native-speaking researcher), current SISC in Tehran were studied. The researchers attempted to answer four main research questions: (1) Which forms of SISC mainly exist in Tehran? (2) Which of the SISC initiatives are joined more often by consumers in Tehran, and why? (3) What are consumers' perceptions about the sustainability potentials of SISC? (4) Which kind of rebound effects could be linked to SISC in Tehran?

The rest of the paper is structured as follows: Section 2 provides a theoretical background for the specific term of SISC and its negative sustainability effects. This is followed by a brief description of the Iranian context. Section 3 states the research methods used in this study. In Section 4, the authors present the most important results of the study. Finally, Sections 5 and 6 discuss the results and highlight research gaps for further investigations as well as conclude the paper.

\section{Literature Review}

Various bodies of literature address topics relevant to answering the research questions of this paper. For the purpose of this study, it is necessary to mainly integrate insights from two fields of social innovations, which refers to the introduction of new social relations and has been a significant topic in 
innovation research $[3,12,13]$, and sustainable consumption, which promotes efficiency, consistency and sufficiency strategies in the consumption alternatives [14]. After that, the contextual conditions (in this study, the Iranian context) in which SISC are evolved are presented.

\subsection{Social Innovations for Sustainable Consumption}

Over the past few decades, in an attempt to study initiatives that offer alternative consumption solutions, researchers have used various terms to make the boundaries of their research clear. Examples of such terms include social innovations, sharing economy [9], eco-efficient services [14], sharing [15] and product-service-system [16], to mention but a few. Although these terms tend to describe similar concepts, they have some differences. For instance, Belk [15] suggests that considering factors such as ownership and compensation for services rendered is essential in determining sharing practices. Manzini and his colleagues [17] define product-service-systems as "a business innovation strategy offering a marketable mix of products and services jointly capable of fulfilling a client's needs and/or wants-with higher added value and a smaller environmental impact as compared to an existing system or product" [17] (27). Various definitions are then suggested for the term "social innovation". Defining this term has not been easy, partially because social innovations do not only have potentials to meet pressing social needs, but also use new social processes to deliver their offers; “In other words, social innovation can refer to both the means and the ends of action" [3] (438). Phills et al. [18] (36) define social innovation as "a novel solution to a social problem that is more effective, efficient, sustainable or just than existing solutions and for which the value created accrues primarily to society as a whole rather than private individuals". Mumford [19] emphasizes that social innovations generate and implement new ideas about how interpersonal activities and social interactions should be organized so that people can meet their common goals. From the perspective of today's European public policy, social innovations are broadly understood as new ideas and new collaborations that can improve effectiveness and at the same time meet social needs [20]. In this study, social innovations are more generally understood "as alternative practices or new variations of practices which differ substantially from established or mainstream routines" [6] (785). Many examples (if not all) of sharing economy examples (e.g., food sharing), eco-efficient services (e.g., laundry salons) or product-service-systems (e.g., car sharing) can also be categorized as "social innovations", since they all aim at changing daily routines. Therefore, social innovations can involve a wide spectrum of initiatives, from energy villages and makerspaces to sharing platforms and online shops.

Many of the alternative solutions (promoted by social innovations) are not new ideas per se. Due to the possibilities offered by digitalization, these solutions have recently enjoyed rapid growth by having access to a broader range of consumers [9]. From online markets for local products to sharing of idling capacities, consumers are experiencing alternative ways of satisfying their needs and desires. Some of these social innovations are offering the same/similar products (e.g., clothing and food) with added value. Others are more innovative and offer alternative consumption patterns by eliminating or decreasing the necessity of ownership (e.g., coworking spaces and ride-sharing platforms). Some examples of such initiatives are often neglected in academic research. One example among the others is online food delivery services, which have only been investigated in a few selected studies as collaborative consumption platforms [21].

Environmentalists discuss that isolated top-down technological innovations cannot promise long-term sustainable development [22,23]. However, grassroots innovations with their bottom-up approaches have significant potentials for responding to the local contexts and interests more effectively [24]. Alternative consumption practices promoted by social innovations claim to be more sustainable than conventional practices carried out by consumers. For instance, they are claimed to be energy-efficient or to reduce waste $[8,25,26]$. With regard to transportation, it has been indicated that car sharing could result in $\mathrm{CO}_{2}$-reduction per average user and that free-floating car-sharing systems could reduce private car ownership [27]. Nijland and Meerkerk [28] also studied the environmental effects of car sharing. The results of their study show that participants in car sharing 
programs own over $30 \%$ fewer vehicles and drive up to $20 \%$ fewer car kilometers than individuals who do not participate [28]. In the case of clothing consumption, it has been claimed that prolonging the usage phase of clothing can decrease the environmental burden of the fashion industry. For instance, if the active life of an item of clothing is extended by nine months, it would potentially result in $27 \%$ carbon saving, 33\% water saving, 22\% waste saving and 22\% resource-cost saving [29].

Besides, the socio-economic benefits of such initiatives cannot be neglected [30]. For instance, community banks in developing countries enable access to monetary resources and empower low-income individuals to be able to start their own businesses [31]. Time banks and skill-sharing platforms are other examples of socio-economic sharing activities. Here, individuals can share their time and skills to profit from non-monetary exchanges.

In sum, amongst a multitude of initiatives in different consumption fields involved in social innovations, it seems that some have great potential for fostering more sustainability regarding environmental as well as socio-economic measures. Despite some academic publications on SISC [6], research on this topic is still in its infancy. For instance, Grimm et al. [3] (436) argue that more theoretical and empirical studies are required "to help social innovation to develop into an effective policy tool".

\subsection{Negative Sustainability and Rebound Effects of SISC}

In order to determine the full scope of the carbon impacts and eco-impacts, it is necessary to analyze all the changes that have been set in motion in the system as a result of a new social innovation (e.g., a sharing practice) [32,33]. For example, if the sale of a household's used items creates earnings that are then used to buy new goods (a so-called "rebound effect"), the practice as a whole may not reduce carbon emissions or have other positive environmental impacts. Another second-round impact can occur if sharing practices shift income across classes because eco-impact per dollar of expenditure varies according to income class. Therefore, in order to have a realistic estimation of the total sustainability effects of SISC, one should also consider their possible negative sustainability impacts, including rebound effects [34]. Participation in SISC could lead to an increase in resource usage, which might even exceed the savings. For instance, if by participating in a SISC, consumers save some money, which, in the end, they spend on an air trip, this might result in an even greater environmental impact. In this regard, any environmental assessment of a SISC must consider the consumers' marginal expenditure in the analyses $[30,35]$.

Researchers have recognized various types of rebound effects. For instance, Santarius [36] (3) identified 13 different types of rebound effects and categorized them into four groups:

- Financial rebound effects "refer to cases in which an increase in energy efficiency results in an income gain and hence in new consumption".

- Material rebound effects "explain how the manufacture and use of more efficient technologies can be accompanied by greater use of energy".

- Psychological rebound effects "explain how the shift to energy-efficient technologies can also boost the symbolic meaning of these goods and services".

- Cross-factor rebound effects "illustrate how increasing the productivity of labor or capital can also increase the demand for energy".

Besides, many eco-efficient and technological innovations, even those with high ecological and socio-economic potential, fail, not only because they tend to neglect the possible rebound effects in their impact calculations but also because consumers do not join them or use their offers [37-39]. Fischer and Barth [40] (194) mentioned that individuals should not only be seen as "objects that need to be pushed in a certain direction, but as co-constructors in a social learning process that is directed towards determining what sustainable consumption is and how it can be achieved". Moreover, Siebenhüner [41] argues that individuals play an important role in (co-)developing social innovations. Besides, Liedtke and her colleagues [39] (106) suggested that "developing product-service systems in user- and stakeholder-integrated settings supports acceptance and diffusion and, by taking into 
account users' social practices of utilizing novelties, reduces rebound effects caused by incorrect application". Knowing about consumers' motivations for joining SISC could be the first step toward a more successful user integration into the processes of developing and even the diffusion of SISC as well as decreasing the rebound effects associated with SISC. Factors influencing the consumer acceptance of SISC are studied in this research. For this, the consumer behavior model of Hawkin and Mothersbaugh [42] is applied. According to this model, various internal and external factors influence consumers' self-concepts and lifestyles; based on their self-concepts and lifestyles, consumers have some needs and desires, which influence their consumption decisions. Moreover, the situational factors are integrated into their model [30].

The negative sustainability impacts and rebound effects of SISC have often been neglected in previous studies. Moreover, there is a lack of studies on understanding the reasons for consumers' acceptance and rejection of engaging in SISC in the Global South. Therefore, in this study, more attention has been given to the factors for consumer acceptance of joining SISC and the possible negative sustainability and potential rebound effects of SISC.

\subsection{SISC in the Iranian Context}

Iran is listed amongst the most populous Middle Eastern countries, with an urban population share of about $75.3 \%$ [43]. The megacity of Tehran, with more than 13 million inhabitants, is one of the most densely populated cities in the world. Among other factors, an increasing concentration of people and a growing vehicle fleet have resulted in high levels of air pollution in Tehran [44]. Tehran was ranked as the sixth most polluted city in the world on 29 November 2019 [10]. Furthermore, public transportation remains limited and insufficient. Tehran is characterized by a high time span spent in traffic jams daily; on average, each citizen spends about $50 \mathrm{~min}$ in a traffic jam on a daily basis in Tehran [11]. Beside such environmental problems, social inequalities are increasing in Tehran. The average Gini coefficient for Iran is about 40, which puts the country amongst those with the highest levels of inequality, in 99th place out of 159 [45]. This index is an important factor for indicating the gap between, for example, the income levels of the richest and the poorest in a society; however, it does not reflect the accessibility to resources. Moreover, regarding Tehran, there are no available data that represent the real income, assets and wealth of the citizens [46].

Similar to in other big cities, recently, a rise in the number of start-ups, non-governmental organizations (NGOs) and grassroot initiatives can be observed in Tehran. About 25 years ago, Bahaee [47] mentioned a lack of market information and government role as two major barriers to entrepreneurial activities in Iran in those years. After 2010, Iranian society made significant efforts to improve the ecosystem for start-ups [48,49]. At the same time, the role of NGOs and social innovations in decreasing the environmental and social problems has been emphasized by some governmental organizations [50]. However, such NGOs are still facing various political, legislative and economic hurdles [50]. An increase in the well-educated young population in the big cities, who are more interested in launching or engaging in new initiatives, can be observed in Iran [48]. This population are the main initiators and users of SISC in Iran; however, there is still a lack of understanding of their perceptions and engagements regarding SISC in Iran.

To the best of the authors' knowledge, except for a recent comparative paper by Schäfer et al. [51], there has been no scientific publication on the issue of SISC in the Iranian context. Therefore, this study aimed at shedding some light on the current situation of SISC in the under-researched context of Tehran, where such initiatives are currently experiencing market growth from supply and demand sides. (Note: in this study "market" includes for-profit (e.g., start-ups) as well as nonprofit (e.g., NGOs) markets. NGOs such as those that rent products for monetary donations could also compete with for-profit organizations in the market. Therefore, it is vital to consider their market share when talking about social innovations, too.) 


\section{Research Methods}

This study was designed as exploratory qualitative research, aiming to investigate and describe the "scene" of SISC in Tehran. In this regard, the researchers resorted to two research techniques: desk research and in-depth semi-structured interviews. First of all, comprehensive desk research was conducted to determine the current examples of SISC in Tehran.

For the desk research, Fink's [52] model, which consists of seven stages, was employed. First, the research question was defined. The overarching goal of this work was to provide an overview of the current existing SISC in Tehran. Second, the search database was selected. The search was conducted in the Google database, as the researchers were not explicitly looking for academic publications but for active initiatives. For this, a broad-based collection of cases was conducted in various consumption fields (e.g., food, energy and mobility), and different sustainability challenges (e.g., waste and energy usage) were considered. A set of keywords was used by a native Persian-speaking researcher to search for the cases in the beginning: ("food" or "clothing" or "mobility" or "energy" or "housing") + ("start-up" + "sharing" + "NGO") + ("sustainable" or "environment " + "nature" + "social"). Several sustainability experts were consulted to determine the final search keywords. In the fourth step, the practical screening criteria were applied. Only initiatives that were claiming (e.g., on their websites) to offer more sustainable services were selected. The initiatives should have also been active at the time of conducting the study. After one round of searching with these keywords, the snowballing method was applied to find and select further cases. The search was continued until no more relevant examples could be found. Among those examples that were very similar (for instance, six different ride-sharing examples), only one of them was considered for further in-depth study. Information necessary for the study of these 40 selected cases was extracted from online sources such as companies' websites, blog entries, brochures, etc. Finally, the results were systematized according to their types of organization and areas of consumption. This desk research provided the researchers with knowledge about the current status quo of available SISC in Tehran, with the limitation that not all SISC might be present on the Internet.

In the next phase of the research, 20 in-depth, semi-structured interviews were conducted with the consumers. The aim of these interviews was to see how consumers were accepting and using the offers provided by initiatives (which were found in the desk research phase) and whether SISC could have any real sustainability benefits. An interview guideline for the interviews was prepared, consisting of general questions about the everyday lives of the interviewees; questions regarding the SISC they knew, joined and regularly joined; questions regarding their estimation of the general sustainability effects of these alternative solutions (based on the three pillars of sustainability: environmental, social and economic); questions regarding financial, material, psychological and time-rebound effects at the individual level of consumption (based on Santarius' [36] categorization of rebound effects); and, finally, demographic questions. The general guiding questions that were used for the interviews are presented in Appendix A.

SISC are currently a new market in Iran; the initiatives are rapidly growing in Tehran. Most of the initiatives identified in the desk research phase are based in Tehran. Therefore, the participants for the interviews were chosen among Tehran's citizens. Moreover, most of the initiatives are found to have a digital nature, which makes them more attractive to the younger population. The older generation in Iran still struggles to adapt to digitalization and to use offers of online platforms. Thus, young consumers (defined as those individuals between 20 and 35 years old) from the city of Tehran were invited to take part in the interviews. Among the interviewees, fifty percent were female, and most of them were employed. Most of them had attained a university degree and were single. They were also asked for their monthly available financial resources (except for household expenses). This income constitutes the financial source that could also be used for participating in SISC. The demographic characteristics of the interviewees are summarized in Table A1 in Appendix B. 
For these interviews, an announcement was sent via several Iranian social media groups. Those who were interested in participating were asked whether they had had any experience with Tapsi or Snap (examples of SISC). These two initiatives were chosen as examples because of their popularity in Iran. Considering the purpose of this study, it was necessary that the interviewees had some firsthand experience with SISC. Among those who had some experiences with SISC, 20 people were randomly selected and invited to the interviews. These people were invited to the interview one by one; after 20 interviews, a repeated trend in the answers was observed by the researchers, and therefore, no more interview was conducted after that. Each interview took about 30 to $45 \mathrm{~min}$, and a monetary incentive was paid to the participants. Interviews were conducted by a native Persian-speaking researcher to eliminate the language barrier between the interviewer and interviewees. The interviews were later transcribed, coded and analyzed using the Atlas.ti software. By applying a qualitative content analysis method, the interview texts were analyzed. After three rounds of coding, the coding process, as well as the codes themselves, were reviewed, modified and validated by another native Persian speaker. This resulted in a total of 291 codes at the end of the coding process.

\section{Results}

The results of this study are presented in two sections. Firstly, the main results of the desk research are showcased. This is followed by the results of the interviews.

\subsection{Results of the Desk Research}

Through an intensive desk research phase, 40 cases of SISC were found in Tehran. A list of all these cases can be found in Table A2 in Appendix C. In the case of having multiple examples of one type, only one example was mentioned with the full information, and the others were only included in the first and last columns of the table.

The initiatives have different organizational types (though most of them are start-ups) and address different areas of consumption (e.g., food, housing, mobility and art). During the desk research, the researchers observed other differences, too. These include the following.

Most of the identified cases are copies of international companies. For instance, in the mobility sector, "Snap" and "Tapsi" are copies of "Uber". Another example would be "Sheypoor" and "Divar". Both of these are copies of "eBay", where consumers can sell their second-hand products. Other cases are more original in the sense that they are addressing a local problem. For instance, there are charity organizations (such as "Klid-e-Behesht") that rent plastic flower stands for funerals. Sending big flower stands to funerals is a cultural norm, and in Iranian funerals, it is often the case that more than 100 people attend. Concerning this cultural norm, the initiative rents plastic flower stands out and then collects, cleans and re-rents them after the funeral. The renting fee is then used for charity purposes.

Another observation was that organizations pursue different goals. "Mamanpaz" is, for instance, a platform where housewives offer self-cooked or excess food to other consumers. This platform is aiming at empowering women who might not have the opportunity to work out of the home. Another initiative, "Keshmoon", not only connects consumers to Saffron farmers, eliminates the middlemen and, in this way, promotes a fair wage for farmers but also educates them about sustainability and water usage and even encourages and promotes the farmers that use less water for their production.

The level of consumer's engagement in different initiatives also varies. Some of the initiatives such as "Finnova-Coworking" offer a service (in this case, coworking space) where consumers participate by using the service. Others are more interactive and acquire more participation from citizens. For instance, "Divar-e-Mehrabani" is an initiative where citizens can find a place in their neighborhood and set it up for sharing and gifting their unwanted clothing. There are also other initiatives such as "Bahamestan", where the more active participation of citizens is required. Here, citizens come together for various initiatives, e.g., to renovate a neighborhood, paint the walls or clean the streets together.

Although the initiatives are sometimes different in terms of their types of organization, the areas of consumption they address, their levels of innovation, their goals and the levels of citizen engagement, 
they still share one commonality: they all offer alternative consumption solutions and promote themselves as having the potential to contribute to more sustainability in Tehran. For instance, on the website of Keshmoon, it is written, " ... Keshmoon helps farmers to sell their own products under their own names and at a fair price... ". On the website of Tapsi, one can read, "... using Tapsi services means using fewer private cars and as a result having less traffic jam and cleaner air. We, in Tapsi, think about creating greater values for the Iranian society ... ".

\subsection{Results of the Interviews}

The results of the interview data are used to answer three main research questions: Which of the SISC initiatives are joined more often by consumers in Tehran and why? What are consumers' perceptions about the sustainability potentials of SISC? Which kind of rebound effects could be linked to SISC in Tehran?

\subsubsection{Social Innovations in Tehran}

At the beginning of the interview, the interviewees were asked to name social innovations with which they were already familiar. Here, most of the interviewees had difficulties in understanding the term "social innovation". The translation of this term into the Persian language is only possible in academic language, and citizens could not understand what the interviewer meant by this term. This problem has been identified in other contexts as well. For instance, Jaeger-Erben et al. [6] mention that social innovation is new, even in academic language. Furthermore, the many terms that are mentioned above could even confuse experts, and it should not be expected to find understanding and consensus about the term "social innovation" from the "broader audience". Therefore, the two examples of "Snap" (ride-sharing initiative) and "Divar" (a platform for selling and buying secondhand goods and services) were mentioned to help explain the term. Here, it should also be mentioned that the participants were asked for "social innovations" and not for "social innovations for sustainable consumption", because the researchers wanted to avoid any bias in the results. After naming the social innovations that the interviewees knew, they were also asked which ones they had ever joined and which ones they regularly joined. The purpose of these questions was to refresh their minds and prepare them for the next round of questions, but also to learn which initiatives enjoyed a broader awareness and acceptance among the consumers.

The results show that almost all the interviewees knew the ride-sharing platforms "Snap" and "Tapsi", as well as the online food delivery platform "Snap Food". Additionally, "Takhfifan" and "Netbarg" (platforms for finding entertainment offers), "Divar" and "Sheypoor" (platforms for selling and buying secondhand goods and services), and "Dijikala" (online shopping platform) were the most well-known examples. Table A3 in Appendix D shows all the initiatives that were named in this part of the interview. Interestingly, most of the social innovations that were mentioned by consumers could be considered as SISC, as they have ambitions to promote sustainability in different consumption areas. This can even be observed regarding online shops and digital money transaction services. The initiators of these, respectively, claim to reduce the amount of transportation and printing paper needed. Another example is food delivery services. Through such online food delivery services, social food initiatives that are promoting, for example, homemade food prepared by housewives, are being promoted, and this way, consumers are becoming informed about such social innovations and can use their offers. Therefore, one can, here, discuss the sustainability advantages of these initiatives and consider them as SISC in the context of Tehran. These initiatives were, here, taken into consideration as SISC for further research steps.

\subsubsection{Consumers' Motivation to Join Social Innovations}

Understanding individual motivations is mentioned as a vital part of research on social innovations [53]. In different studies on initiatives that offer alternative consumption solutions, it could be shown that consumer acceptance is the most critical success factor for such initiatives [54]. Therefore, 
it is vital to study the reasons affecting consumers' acceptance of SISC. In this study, various reasons were mentioned by the interviewees for joining SISC or using the services they provided. Considering the model of consumer behavior suggested by Hawkin and Mothersbaugh [42], the reasons mentioned by the interviewees were classified into five groups: internal motives, external motives, situational motives, lifestyles, as well as features, and the possibilities that SISC are offering (consumption decision).

Internal influences: sustainability motives were mentioned by a few participants. For instance, to answer the question "why did you decide to use the offers of these social innovations?", Interviewee \#6 said, " ... for instance, Tapsi has added an option called Tapsi-line, which allows you to carpool with others. This leads to decreasing the costs as well as a cleaner city, as it decreases solo drivers.". Environmental motives such as "decreasing air pollution" and socio-economic motives such as "eliminating middle-men" were mentioned as factors influencing their decisions about using alternative consumption offers. Moreover, "Being curious about new technologies" and "just to have fun" were other factors mentioned by consumers for engaging in these initiatives.

External influences: cultural motives were mentioned as reasons for joining SISC. Six participants pointed out that they liked using SISC offers to "avoid face-to-face embarrassment". Cultural and social norms in Iran can cause some complications and awkward social situations. For instance, a number of people found it embarrassing to enter a shop and ask about various products' features and prices and, at the end, leave the shop without purchasing anything. Another example is about ride-sharing offers. Interviewee \#17 mentioned, "If you call a taxi you should say I want to go from here to there and then ask how much the ride would cost and then negotiate the price. But ride-sharing is very easy. Because many people do not like to negotiate. In the ride-sharing applications, you can easily see and check the price". This is also special for the Iranian context, where the prices of taxis are usually negotiable. Applications are now eliminating such negotiations, and therefore, online platforms can prevent such unpleasant situations.

Situational motives: seven participants mentioned that these initiatives offer "more safety". For instance, in the case of using ride-sharing options, they could track and share their routes with a third person. This way, there was less chance of being, for example, kidnapped by taxi drivers. Fo women, these ride-sharing options could decrease the chance of being sexually assaulted. For instance, Interviewee \#13 said, “ . . ride-sharings are relatively safe. Because if you are in a suburb, you can not trust every driver that drives by; but those, who work as Snap-drivers need to pass some filters and be more careful.". However, some of the participants also claimed that, sometimes, they used these offers because there was no better option for them on the market. Interviewee \#16 said, "Ride-sharings are more helpful in urgent matters. For instance, you need to go somewhere, that you can not go by private-cars or you are in a hurry, and you know that you can not find parking-spot there, it is better to use services of Snap or Tapsi".

Lifestyles: "increasing ease and quality of life" (15 participants) and "decreasing living costs" (13 participants) were among the main motives mentioned by consumers for engaging in SISC. Interviewee \#11 mentioned, "Because we (my husband and I) are very busy. We only have $4 \mathrm{~h}$ a day to do other things than working or sleeping. So, joining these initiatives, we can use these $4 \mathrm{~h}$ to rest a bit more or have more quality in our lives instead of spending those hours also for grocery shopping or in a traffic jam.". Interviewee \#1 said, "Snap and Diji-Kala have increased the ease of life for me as well as decreased my living costs".

Features and possibilities that SISC are offering: most of the interviewees (12 participants) mentioned that "speeding up the pace of life" was the main reason for them to use the alternative emerging solutions. For instance, Interviewee \#7 said, "I use services offered by Snap and Tapsi because it increases the speed of my life". Other main reasons were mentioned as "offering higher quality", "having more options" and the "trust and transparency" of these initiatives. For instance, Interviewee \#7 mentioned, "(For Snap and Tapsi) you can pay the fee online. This way, they can not ask for more money. Also, because there is a company that controls the transactions. You know that it is safe, and if something happens to you, the company will respond to your complain. The former taxi-services 
were not so customer-friendly and responsive". Moreover, these initiatives provide more information about the available options. For instance, online food delivery platforms provide a list of restaurants and cafés that otherwise could not be easily found by consumers. It has been also mentioned that consumers could know about, for example, social food initiatives only because they found information about them on such online platforms. "Accessibility", "ease of use" "being customer-oriented" and the "flexibility" of these initiatives were also mentioned as reasons for preferring and joining them. Finally, having and offering various forms of "discounts" was mentioned as being one of the main motives for consumers of these SISC.

\subsubsection{Perceived Sustainability Advantages of SISC}

The participants were asked to discuss the sustainability benefits of SISC. As it was unclear whether the interviewees could understand the term "sustainability", three questions were asked regarding the environmental, social and economic benefits of SISC, respectively. These questions helped the research team to understand to what extent the participants thought that SISC could benefit the three pillars of sustainability (ecological, social and economic). More than two-thirds of the interviewees believed that SISC had some ecological and economic benefits, whereas almost all of the interviewees believed that SISC had social benefits.

\section{Ecological Benefits}

When talking about the ecological benefits of SISC, most consumers talked about mobility and online shopping practices. Most of the interviewees believed that SISC could have environmental benefits, as they lead to "less usage of private cars and fuel", "less traffic jam in the city", "less air pollution" and "less parking spaces needed". Interviewee \# 16 said, "for example, Bidood, a bike-sharing initiative, could have positive environmental influences. The same for Snap and Tapsi ... when people do not use their private cars and in the pick of traffic use bike-sharing or ride-sharing to for example come back home from work, the traffic jam will be decreased, and this has huge ecological benefit.". Other ecological benefits of these SISC that were mentioned include "less paper usage" (e.g., for money transactions), the "reusing of products" (through second-hand online platforms) and the "using of idling capacities" (e.g., ride-sharing).

\section{Social Benefits}

"Increasing ease of life" and "time-saving" (e.g., less cooking, shopping and cleaning needed) were mentioned as social benefits of SISC. Interviewee \#14 said, "engaging in these initiatives decreases my living costs, but what is very important to me is the fact that they save time for me. I don't have time to spend half a day to go to a special Bazar and buy, for instance a headset". Other social benefits were claimed to be "increasing job opportunities" (e.g., ride-sharing drivers), "maintaining social interaction" (e.g., in coworking spaces), "increasing satisfaction in the society" and "less anger in the society". Interviewee \#2 said, "I think these initiatives have many benefits. By using them, people could be less annoyed. For instance, our street name is a kind of name that people can not easily understand it on the phone. But now (when I want to call a cab) I just need to enter our street's name in online platforms, and this saves time". Moreover, "becoming open toward change in the society" and "causing a big transformation in Iran" were mentioned to be among the other social benefits of alternative consumption solutions. For instance, about the Keshmoon initiative, Interviewee \#20 said, "I think the farmers can be seen in this way. I mean the farmers always have had this feeling that they were getting neglected, but now they can feel that they are also being seen and they can be in contact with people (their customers) from big cities...from consumers' side, they can acquire some information about the lives of those (farmers), who are living far away and they can understand how they (farmers) think and live... This connection will cause a big change in the whole society". Such initiatives can foster transparency about the production side and help to decrease the existing gap between different social classes in society. 


\section{Economic Benefits}

Most of the participants mentioned that SISC could result in "saving money" for users and "earning money" for providers. Moreover, they provide a "competitive market", in which the quality of goods and services is increased, and more reasonable pricing for goods and services is set up. Interviewee \#10 said, "These initiatives caused a competitive market. As a result, better services are now offered to consumers and consumers have more choice and power". SISC can also expand the market opportunities and attract more customers through "increasing the awareness about available services and options", "eliminating middle-men", "decreasing associated costs of traditional businesses" and "increasing money circulation in the society", which were all other economic benefits of SISC mentioned by participants.

\subsubsection{Perceived Negative Sustainability Impacts of SISC}

Participants were also asked whether SISC might have any negative influence in terms of sustainability. Here, again, three questions based on the three sustainability pillars were asked. In comparison to the question regarding the sustainability benefits of SISC, fewer interviewees believed that SISC could have some negative influences.

\section{Ecological Disadvantages}

"Consuming more resources" and "impulsive purchasing" (e.g., due to the convenience and ease of use of services), "less using of public transportation" (e.g., because of inexpensive ride-sharing offers), and "more air pollution" and "more traffic jam" (e.g., because of inexpensive ride-sharing offers) were mentioned as the most important possible negative ecological impacts of alternative consumption solutions. Interviewee \#10 said, "Back when there was no ride-sharing option, I was rarely calling a cab because of the high prices of the taxis. And therefore, most of the time I was using public transportation. But since ride-sharing initiatives, such as Tapsi and Snap are launched, I almost never use public transportation". Other possible disadvantages were "more packaging used for sending products" (e.g., online food delivery) as well as "less governmental incentives for traditional businesses" (e.g., less/no incentive for replacing old taxi-vehicles).

\section{Social Disadvantages}

The most significant social disadvantage of SISC that participants mentioned was "some people are losing their jobs". For instance, taxi drivers cannot compete with inexpensive and convenient ride-sharing offers. Furthermore, some older adults do not know how to use computers or smartphones and therefore cannot benefit from these new services. For instance, Interviewee \#2 said, "When my dad is alone at home, he can not use food delivery systems and order food for himself. If he knew how to use the applications, it could have been way better for him. But you know these online-platforms are not easy for him to use". Another issue surfaced among educated people who were currently working in unrelated jobs. For instance, many cases were observed in which a person with a master's degree worked as a ride-sharing driver. In this regard, resources that were invested in educating these people were perceived as being wasted. Due to the current economic instability and high inflation as well as unemployment rates in Iran, such well-educated people are having difficulties in finding adequate jobs. Ride-sharing drivers are considered to be from lower social classes, and some passengers display impolite behavior towards them.

Some participants mentioned that services such as online food delivery platforms "make people lazy". Some of these initiatives also caused a new form of "homelessness". For instance, some people from rural areas or smaller cities are coming to Tehran to work as ride-sharing drivers to earn money, and they have to spend nights in their cars without any access to hygiene facilities. Other social disadvantages were mentioned to be "people becoming less patient (they are getting used to a faster pace of life)", "less social interaction" and a "lack of legal regulation and monitoring of these initiatives". 
For instance, Interviewee \#13 talked about the Divar Initiative, which is a copy of eBay. He said, "there is still a lack of legal regulations for these initiatives that could control the transactions. Unfortunately, all is depending on the seller and buyer at the moment. It has happened many times that my colleagues bought something and paid for the product, but never have received it or could never reach the seller again. There was no way that they could claim their money back".

\section{Economic Disadvantages}

Most of the interviewees mentioned that these alternative consumption solutions caused the "elimination and extinction of some jobs". For instance, local shops and neighborhood supermarkets are going out of business because they cannot offer the same prices for their goods and services. Interviewee \#4 said, “Tapsi and Snap made some jobs for unemployed people and these drivers could have a job and earn more money, but on the other hand, traditional taxi-services could not compete with these new initiatives and had to close their businesses". Some participants mentioned the "unfair salaries of those who work for these alternative services" as one economic disadvantage. Another problematic factor here that was mentioned was "controlling the pricing strategies of goods". For instance, online-shopping platforms can increase the prices of cars in a few hours, and there is no governmental authority monitoring their actions. Other economic disadvantages that were also named included the "privatization of some systems, e.g., transportation" and "monopoly of some services".

\subsubsection{Rebound Effects at the Individual Level}

The participants were also asked to explain how these SISC influenced their personal lives. For instance, they were asked how they used the money that they saved using these services or how they used the time saved through engaging in SISC.

\section{Financial Rebound Effects}

Most of the participants (12) claimed that using SISC had decreased their living costs. These individuals were then asked what they did with the available/saved money. Almost half of them answered that they used the available money to purchase more stuff. For instance, Interviewee \#10 said, "I buy other stuff, that are not necessary. In other words, I waste my money". The other half claimed that they spent this money on other living costs (e.g., food, rent and paying off loans) to be able to maintain their quality of life. They mentioned the current unstable economic situation of Iran and the fact that the prices of goods have been dramatically increased so that even if they could save money through joining these SISC, they had to pay more in other parts of their lives. Additionally, participants mentioned that they spent this money on more entertainment in their free time or saved it for starting a job later.

\section{Material Rebound Effects}

Half of the participants said that because of alternative consumption solutions, "they use more goods and services" now. For instance, they engaged in ride-sharing more frequently and used less public transportation. Some mentioned that they ordered more food to be delivered to them. "Impulsive purchasing" on online platforms for purchasing new or second-hand goods was pointed out by some participants, too. For instance, Interviewee \#10 said, "now when I have some free time, I go to Diji-Kala Platform and scroll through its' discount part. Usually, I find amazing things there. Then I say, wow! How much did I need this and how inexpensive this became now! And then I buy it".

\section{Psychological Rebound Effects}

Most of the participants reported that they "feel good" after using these services. Feeling "more relaxed" and "having less stress" in daily life was mentioned by nine participants. Eight participants mentioned that they felt "being up to date" and modern after engaging in SISC. Some participants 
(four) claimed that they treated themselves when they used alternative consumption offers because they felt they did something right. Interviewee \#4 claimed that she was saving money by engaging in these initiatives, and then, she said, "then I treat myself every week because of my savings. I always tell myself: if you save more money, you can buy other things with it later. And this way I encourage myself to save more money".

\section{Time Rebound Effects}

In this part, the participants talked about how they used the time that they saved by practicing alternative consumption. Here, one could categorize what they mentioned into two groups of positive and negative time use.

On the one hand, some participants claimed that they used this time to rest more; to read more; $t$ perform personal and hygiene duties more easily and in a more relaxed manner; to do things they liked, such as painting; to have more fun time; or to have more social interaction. On the other hand, some participants claimed that they used this time to do more multitasking and use time more intensively for daily chores, to work more or to consume more. For instance, Interviewee \#5 said, "sometimes I have to finish a task, and at the same time I need to purchase some stuff, through these platforms I can do both at the same time. Without these initiatives, I could only do one of them. But about Snap and Tapsi: if I don't use their offers, I need to get up earlier and can not have enough rest".

\section{Discussion}

Studying the sustainability potentials of social innovations has recently been of interest to some researchers [24]. In order to harness the potential of SISC, not only should initiatives reach consumers and motivate them to engage in their initiatives [24,55], but it is important that consumers also realize the further sustainability potential of these initiatives and engage in them in a way that the sustainability benefits offered by such alternative solutions are not overshadowed by their possible negative sustainability or rebound effects. This explorative study shed some light on this complex phenomenon in the Iranian cultural context.

\subsection{Discussion of the Variety of SISC in Tehran}

Iran is currently enjoying a growing market of different SISC. These initiatives, with different types of organization, focus on various consumption fields and demand diverse levels of citizen engagement. Most SISC cases in Tehran are copies of international ideas/companies (e.g., "Divar" and "Sheypoor" are copies of "eBay"). Looking at consumer awareness of SISC in Tehran, one can see that such initiatives are well-known by almost all young consumers. This could be due to the fact that such initiatives are more technologically oriented and, therefore, they are more interesting for the younger generation (who were the sample of this study). Another reason could be that Iranian youth are mostly following trends in Western culture and are interested in keeping up with the Western trends. From a business perspective, these initiatives could also enjoy a ready-made idea and design that "only" needs to be adapted and implemented in the Iranian context. This makes the barriers to entry for such initiatives in a new country much lower. Moreover, their offers are new for the Iranian consumers, and the local offers cannot compete with these initiatives. A good example of this could be traditional taxi-services versus ride-sharing initiatives such as Tapsi. By contrast, local initiatives require more investment to attract brand awareness and educate consumers towards altering their behaviors. An example of this could be the "Keshmoon" initiative. This was among the first initiatives that offered a direct producer-to-consumer platform in Iran. In comparison to ride-sharing and online shopping platforms, such initiatives have difficulties in attracting users.

Furthermore, joining some SISC and carrying out some practices requires more involvement and engagement from the consumers' side in comparison to others. For instance, the organizing and regular cleaning of the parts of neighborhoods that are dedicated to "Divar-e-Mehrabani" for clothing 
exchanges demands more engagement from the users' side compared to using ride-sharing services. However, still, except for a few cases (e.g., Bahamestan), most of the SISC in Tehran require a rather low level of engagement and communality from the users' side compared to SISC in other country contexts (e.g., in Germany) [6]. For instance, no example of urban gardening or energy cooperatives could be found in Tehran. Besides, initiatives that are resulting in greater convenience, cost-saving and time-saving seem to be more successful in attracting consumers. Considering the aforementioned issues of living in a megacity together with the current economic instability in Iran, these advantages of SISC could increase the quality of life of citizens. Satisfying the need for variety, increasing convenience and offering greater safety could also be considered as the most important aspects of SISC for consumers.

Moreover, most of the successful initiatives (in terms of having more users) in Tehran are initiatives that offer mobility solutions. Ride-sharing initiatives such as "Snap" and "Tapsi" and online shopping/secondhand platforms such as "Divar" and "Dijikala" are some examples of these initiatives. These initiatives are addressing some of the main issues (e.g., traffic jams and air pollution) that citizens of the highly populated city of Tehran are facing and suffering from on a daily basis.

\subsection{Discussion of Possible Positive and Negative Sustainability Effects}

Concerning the sustainability impact of SISC, the number of interviewees who listed sustainability benefits for SISC was higher than the number of those who mentioned some negative sustainability impacts or rebound effects for these initiatives. Therefore, generally, a more positive perception of the sustainability benefits of SISC could be observed. The mobility focus in Tehran could also be observed during the discussions on the sustainability benefits of SISC. Most of the interviewees believed that SISC could result in a reduced usage of private cars and fuel, fewer traffic jams in the city and less air pollution; furthermore, it could also result in greater convenience, more time-saving, and increased mini-job opportunities, as well as providing an increasingly competitive market.

The discussion on the sustainability impacts of SISC in Tehran revealed a need for the consideration of situational factors in measuring such impacts. For instance, the ecological benefits of online delivery platforms when compared to individual purchases cannot be easily measured [56,57]. It can be argued that individual purchases could be combined with other activities, such as driving to the office. In this way, the individual purchases could be less environmentally harmful than online delivery systems. Besides, the extra packaging needed for transporting the products can have negative sustainability impacts. However, one must consider the fact that in Tehran, there are still particular markets for different categories of products. For instance, if someone would like to purchase a washing machine and a bag, he or she would need to visit two different markets, which are usually located far away from each other in two different parts of the city, requiring at least one hour of driving to travel from one market to the other. Before the emergence of online shopping platforms, average consumers went to the main markets to purchase the goods they would have liked to obtain. This was also mentioned by the interviewees. Now, all the products can be purchased using online platforms, and people do not have to spend their time individually driving to the markets. Moreover, the interviewees believed that they could use these online platforms to compare the prices and then have the option of choosing the least-expensive products. It seems that online delivery systems in a crowded city such as Tehran with an insufficient public transportation system and decentralized markets might bring some ecological benefits. Other researchers also claim that under specific conditions (e.g., the combining of delivered products), online shopping might serve to reduce the carbon footprint when compared to conventional shopping [58]. Besides, by using online platforms, some underprivileged individuals could be empowered, as these digital platforms reduced geographical barriers to, for example, selling homemade or handmade products.

When talking about the possible negative sustainability impacts of SISC, more than half of the interviewees mentioned the fact that due to the emergence of SISC (especially in the mobility and retailing sectors), many jobs have been lost. For instance, small shops cannot keep up the low prices offered by big online shopping platforms. This will directly affect some groups more 
than others (e.g., elderly or less-educated people). Another example could be platforms that are offering various home-care services. It is argued that these platforms are promoting a series of small-scale agreements between individuals rather than creating secure jobs [59]. Such transitions in the labor market have previously been mentioned as a consequence of the alternative economies (e.g., sharing economy) [59,60]. It can be argued that the mentioned disadvantages are common pitfalls of the digitalization of services or introduction of an innovation, but they could still be seen as economic sustainability disadvantages of SISC, too. Other disadvantages that were mentioned included increased resource consumption and less use of public transportation, as ride-sharing offers are affordable.

Alternative SISC solutions could be more eco-efficient. However, if individuals do not adjust their behaviors, these might not result in any benefit, or, at least, their ecological potential cannot be fully met. For instance, many participants of this study claimed that by engaging in SISC, they saved money. However, if they use this financial benefit to consume more later, they contribute to the rebound effect, and as a result, the sustainability benefits of SISC might be diminished. This risk has been mentioned in studies of the sharing economy, too [61]. The interviews could reveal different types of rebound effects as consequences of changes to individual behavior resulting from engaging in SISC. Financial, material and psychological rebound effects that were extracted from self-reported behaviors reveal the precarity of the sustainability gains resulting from SISC when individuals are unaware of the rebound effects. Almost all of the interviewees claimed that SISC helped them by saving some time in their daily lives. Knowing how they use this saved time could help the researcher to see whether they are engaging in additional resource-intensive activities or not. Most of the participants claimed that by engaging in SISC, they could have some more free time in their lives, which they, in turn, used to rest more or to have time for reading. Some other participants reported using the saved time to become more efficient and to do more multitasking or to work more. Considering the city of Tehran as the context of this study, having some time for resting or reading could be seen as a positive outcome of engaging in SISC.

\subsection{Limitations of the Study}

This study is among the first to tackle the phenomenon of SISC in an Iranian context and has some limitations. First of all, as the term "social innovation" has only a scientific translation in the Persian language, two examples were mentioned to the interviewees at the beginning of the interviews. This might have resulted in bias in their answers and the fact that they talked mostly about start-ups and not much about NGOs. Moreover, this is a qualitative, explorative study: the researchers did not seek representative sampling. Further empirical research could build upon the results of this study by integrating a larger sample. In this paper, the authors shed some light on the concept and the current status quo of SISC in Tehran. Further investigation could work out a typology for SISC in developing countries. Moreover, more extensive research could further shed light on the rebound effects associated with the SISC. For instance, future research could more extensively address the question of how consumers are spending resources (e.g., time and money) that they save through engaging in SISC. More empirical cross-cultural research using more cases from different countries could help researchers to understand the differences and similarities of SISC in different country contexts.

\section{Conclusions}

In conclusion, it seems that SISC, especially the ones that are copies of international companies, are widely accepted by consumers. Most of these SISC have a high potential for fostering more sustainable practices. However, there is still a lack of comprehensive understanding of the absolute sustainability impacts of these initiatives. Looking at the consumers' motivations for engaging in SISC in Tehran, one could discuss a range of different motives, from saving money to decreasing environmental problems. For instance, in a megacity such as Tehran, saving time and, accordingly, increasing the quality of life seem to be an important motive for consumers to engage with SISC. 
Further quantitative research could investigate the influence of egoistic, altruistic and biospheric motives on consumers' acceptance of SISC in Tehran. Consumers have a rather positive perception that by engaging in SISC, they are contributing to achieving greater sustainability; however, they are not aware of the possible negative sustainability and rebound effects of SISC. Integrating consumers into the process of developing and implementing SISC and educating them about the absolute sustainability effects of these initiatives as well as the correct application of the alternative offers of SISC could result in greater success for these initiatives in terms of their contribution to sustainability. It is also emphasized that in the Middle Eastern region, "an interlink between social innovations and sustainable development needs to be realized more with the aim of finding solutions to the root causes, rather than just the symptoms." [62] (145). For solving some of the sustainability issues in Tehran, more collective collaborations between different stakeholders (e.g., the government, users and the founders of the initiatives) is needed.

Finally, the presented estimations of and discussions on the sustainability impacts of SISC in Tehran are based on the results of desk research and self-reported qualitative interviews. For the precise measurement of the sustainability effects of these initiatives, extensive life cycle assessment studies on the alternative consumption solutions offered by the initiatives and the way in which users are consuming such offers are required. This paper is dedicated to mainly providing a basis for such quantitative studies in the future.

Author Contributions: Conceptualization, S.I. and M.M.; Funding acquisition, M.M.; Investigation, S.I.; Methodology, S.I.; Supervision, M.M.; Validation, S.I.; Writing—original draft, S.I.; Writing—review \& editing, S.I. and M.M. All authors have read and agreed to the published version of the manuscript.

Funding: This research received no external funding. The open-access fee of the publication is paid by Ulm University.

Acknowledgments: The authors would like to thank all the interview participants for sharing their insights and experience for the purpose of this study. Furthermore, the authors are thankful to the financial support programs for female scientists at Ulm University for their support during the conducting of this study. Besides, the author would like to thank all the colleagues, sustainability experts and reviewers, who supported them by their constructive feedback to improve the quality of the paper. Special thanks go to Arman Fathejalali for reviewing, modifying and validating the interview codes as a Persian-speaking researcher.

Conflicts of Interest: The authors declare no conflicts of interest. The funders had no role in the design of the study; in the collection, analyses or interpretation of data; in the writing of the manuscript; or in the decision to publish the results.

\section{Appendix A Interview Guideline}

1. Could you please tell what does a typical day in your life looks like? What activities are you doing from morning till evening?

2. What social innovations do you know in Tehran? (examples of social innovations for elaborating the term: Snap and Divar).

3. Which of these social innovations have you ever participated in?

4. Which ones do you regularly participate in?

5. Why did you decide to engage in these social innovations and/or use their offers?

6. What changes are you observing in your life because of using the offers provided by these initiatives?

a. What monetary influences have engaging in these initiatives on your expenditures? (For instance, do you save money by engaging in these initiatives?)

i. If they save money: What do you do with the money you saved?

b. How do you feel about using the offers provided by these social innovations? (For instance, do you treat yourself because of using their offers?)

c. What impacts have engaging in these initiatives on your time resources? 
i. If they save time: what do you do with the time you saved because of using their offers?

7. What influences do you think these social innovations have on the environment, economic and social factors? Could you please elaborate on your thoughts in this regard?

a. What are the sustainability benefits of SISC?

b. What are the sustainability disadvantages of SISC?

8. Demographic questions: gender, age, education, job, marital status, having child/children, disposable income

Note: Depending on the conversation, the questions were sometimes modified during the interview or further questions were asked,

\section{Appendix B}

Table A1. Demographic characteristics of the interviewees.

\begin{tabular}{|c|c|c|c|c|}
\hline Gender & Female & Male & & \\
\hline \multirow{3}{*}{ Age } & 10 & 10 & & \\
\hline & $20-24$ & $25-29$ & $30-35$ & \\
\hline & 9 & 4 & 7 & \\
\hline \multirow[t]{2}{*}{ Education } & High School & Bachelor & Master & $\mathrm{PhD}$ \\
\hline & 2 & 8 & 9 & 1 \\
\hline \multirow[t]{2}{*}{ Occupation } & Yes & No & & \\
\hline & 16 & 4 & & \\
\hline \multirow[t]{2}{*}{ Marital Status } & Single & Married & & \\
\hline & $\begin{array}{l}13 \\
\text { Yes }\end{array}$ & $\begin{array}{c}7 \\
\text { No }\end{array}$ & & \\
\hline Having a child & $\begin{array}{c}\text { Yes } \\
1\end{array}$ & $\begin{array}{l}\text { No } \\
19\end{array}$ & & \\
\hline \multirow{2}{*}{$\begin{array}{l}\text { Monthly available financial } \\
\text { resources except for } \\
\text { household expenses }\end{array}$} & $0-50 €$ & $51-200 €$ & $201-400 €$ & No answer \\
\hline & 9 & 7 & 2 & 2 \\
\hline
\end{tabular}




\section{Appendix C}

Table A2. List of the SISC found in the desk-research phase.

\begin{tabular}{|c|c|c|c|}
\hline Case (Examples) & Type of Organization & Area of Consumption & Reference \\
\hline $\begin{array}{l}\text { Initiative for providing women with } \\
\text { working opportunities (Mamanpaz) }\end{array}$ & Private company & Food & https://www.mamanpaz.ir/ \\
\hline $\begin{array}{l}\text { Initiative for community supported } \\
\text { agriculture (Keshmoon) }\end{array}$ & Private company & Food & www.keshmoon.com \\
\hline $\begin{array}{l}\text { Platform for food donation (4379-Yek } \\
\text { Loghme Mehrabani) }\end{array}$ & Network & Food & https://t.me/s/yekloghmemehrabani \\
\hline $\begin{array}{l}\text { Initiative for fair trade of agricultural } \\
\text { products (Khunegia) }\end{array}$ & Private company & Food & http://khonegia.ir/ \\
\hline $\begin{array}{l}\text { Platform for fair trade art pieces } \\
\text { (Bazartche) }\end{array}$ & Private company & Art, Design & http://bazartche.ir/ \\
\hline $\begin{array}{l}\text { Platform for fair trade handmade } \\
\text { upcycled products (Charogh, Plusup) }\end{array}$ & Private company & Waste, Design & $\begin{array}{l}\text { http://charogh.com/ } \\
\text { http://plusup.ir/ }\end{array}$ \\
\hline $\begin{array}{l}\text { Platform for fair trade of handmade } \\
\text { pieces (Neekzee, Basalam) }\end{array}$ & Private company & Art, Design & $\begin{array}{l}\text { http://neekzee.com/ } \\
\text { https://basalam.com/ }\end{array}$ \\
\hline $\begin{array}{l}\text { Platform for trade of handmade goods } \\
\text { produced by housewives } \\
\text { (Sharikemaman) }\end{array}$ & Private company & Art, Design & www.picuki.com/profile/sharikemaman \\
\hline Car sharing initiatives (Carvanro) & Private company & Mobility & http://carvanro.com/ \\
\hline $\begin{array}{l}\text { Platform for ride-sharing inside cities } \\
\text { (e.g., Hampasho, Snap, Tapsi) }\end{array}$ & Private company & Mobility & $\begin{array}{c}\text { https://myket.ir/app/com.hampa } \\
\text { https://snapp.ir/ } \\
\text { https://tapsi.ir/ }\end{array}$ \\
\hline $\begin{array}{l}\text { Platform for ride-pooling between cities } \\
\text { (e.g., 4Paaye, Bahamsafar) }\end{array}$ & Private company & Mobility & $\begin{array}{c}\text { http://4paaye.ir/ } \\
\text { http://bahamsafar.com/ }\end{array}$ \\
\hline
\end{tabular}


Table A2. Cont.

\begin{tabular}{|c|c|c|c|}
\hline Case (Examples) & Type of Organization & Area of Consumption & Reference \\
\hline Bike sharing platform (Bidood) & Private company & Mobility & http://bdood.ir/ \\
\hline $\begin{array}{l}\text { Online peer-to-peer sharing platforms } \\
\text { for clothing (Komoda) }\end{array}$ & Network & Clothing & www.komodaa.com/ \\
\hline $\begin{array}{l}\text { Offline initiative for garment-sharing } \\
\text { (Divar-e-Mehrabani) }\end{array}$ & Engaged individuals & Clothing & $\begin{array}{l}\text { www.en.wikipedia.org/wiki/Wall_of_ } \\
\text { kindness }\end{array}$ \\
\hline $\begin{array}{l}\text { Luxury garment rental shop (e.g., } \\
\text { Sitrabokaei, Bazmineh, Joorpin) }\end{array}$ & Private company & Clothing & $\begin{array}{c}\text { https://bazmineh.com/vendor/miniator- } \\
\text { bridal-meson } \\
\text { https://www.luxomajlesi.com/bridal- } \\
\text { dress-rental/ } \\
\text { https://joorpin.ir/cat/24/ }\end{array}$ \\
\hline $\begin{array}{l}\text { Platform for selling and swapping (e.g., } \\
\text { Sheypoor, Divar) }\end{array}$ & Private company & $\begin{array}{l}\text { Clothing, electrical } \\
\text { devices, books, etc. }\end{array}$ & $\begin{array}{l}\text { https://www.sheypoor.com/ } \\
\text { https://divar.ir/ }\end{array}$ \\
\hline $\begin{array}{l}\text { Platform for house sharing (e.g., } \\
\text { Moosem, Shab, Vila-Jar, Jabama) }\end{array}$ & Private company & Housing & $\begin{array}{c}\text { https://www.moosem.ir/ } \\
\text { https://www.shab.ir/ } \\
\text { https://www.vilajar.com/ } \\
\text { https://www.jabama.com/ }\end{array}$ \\
\hline $\begin{array}{c}\text { Financial institute } \\
\text { (Sandogh-e-Gharzolhasan-e-Farhangian) }\end{array}$ & Association & Funding & http://www.fnbank.ir/ \\
\hline $\begin{array}{l}\text { Platform for urban integration } \\
\text { (Bahamestan) }\end{array}$ & NGO & Urban living & https://www.bahamestan.net/ \\
\hline $\begin{array}{l}\text { Initiative for plastic flower rental } \\
\text { (Kelid-Behesht, Rajeoon, Taajgol) }\end{array}$ & NGO & Waste, Cultural rituals & $\begin{array}{c}\text { https://www.kelid-behesht.com/ } \\
\text { https://www.rajeoon.com/ } \\
\text { http://www.taajgol.com/ }\end{array}$ \\
\hline Platform for book exchange (Ghafase) & Network & Books & https://ghafa3e.ir/ \\
\hline $\begin{array}{l}\text { Co-working space (e.g., } \\
\text { Finnova-Co-working) }\end{array}$ & Private company & Furniture, Devices & http://finnova.ir/ \\
\hline $\begin{array}{l}\text { Offline charity platform (e.g., } \\
\text { Kahrizak-Secondhand) }\end{array}$ & NGO & $\begin{array}{l}\text { Household items, furniture, cloths, toys, } \\
\text { etc. }\end{array}$ & http://kahrizak.com/ \\
\hline $\begin{array}{l}\text { Platform for space sharing } \\
\text { (Couchsurfing) }\end{array}$ & NGO & $\begin{array}{l}\text { Housing } \\
\text { Travel }\end{array}$ & www.couchsurfing.com/places/iran \\
\hline
\end{tabular}


Table A2. Cont.

\begin{tabular}{ccc}
\hline Case (Examples) & Type of Organization & Area of Consumption \\
\hline $\begin{array}{c}\text { Platform for collecting recyclable } \\
\text { garbage (Zistapp) }\end{array}$ & NGO & Waste \\
\hline $\begin{array}{c}\text { Platform for repairing and renovating } \\
\text { services (e.g., Ostadkar, Achareh) }\end{array}$ & Private Company & Household \\
\hline
\end{tabular}

\section{Appendix D}

Table A3. List of SISC cases mentioned by interviewees.

\begin{tabular}{|c|c|c|c|}
\hline \multirow[t]{2}{*}{$\begin{array}{c}\text { Areas of Consumption and General } \\
\text { Description of SISC }\end{array}$} & \multicolumn{3}{|c|}{ SISC (Name of Initiatives) That Interviewee ... } \\
\hline & ... knows about & $\ldots$ has ever engaged in & $\ldots$ is regularly engaging in \\
\hline \multicolumn{4}{|c|}{ Clothing } \\
\hline Online shopping & $\begin{array}{c}\text { Diji Style, Modise, Saloome, Calina, Bani } \\
\text { Mode, Astin }\end{array}$ & Diji Style, Modise, Saloome, Calina, Astin & - \\
\hline Local designer-products & Komod & Komod & - \\
\hline Online 3-D trying & Ray Ban & Ray Ban & - \\
\hline \multicolumn{4}{|c|}{ Food } \\
\hline Online platform & $\begin{array}{l}\text { Snap Food, Bamilo, Fidilio, Reyhoon, } \\
\text { Cheliveri, Boghche }\end{array}$ & $\begin{array}{c}\text { Snap Food, Bamilo, Fidilio, Reyhoon, } \\
\text { Cheliveri }\end{array}$ & Snap Food \\
\hline Rating restaurants & Foursquare & Foursquare & - \\
\hline Sharing food recipes & Lezzat-e-Ashpazi, Sanaz-Sani & - & - \\
\hline Online supermarket & Ofogh-e-Kourosh, Snap Market & Ofogh-e-Kourosh, Snap Market & - \\
\hline
\end{tabular}


Table A3. Cont.

\begin{tabular}{|c|c|c|c|}
\hline $\begin{array}{c}\text { Areas of Consumption and General } \\
\text { Description of SISC }\end{array}$ & \multicolumn{3}{|c|}{ SISC (Name of Initiatives) That Interviewee ... } \\
\hline \multicolumn{4}{|c|}{ Mobility } \\
\hline Ride-sharing & $\begin{array}{l}\text { Snap, Tapsi, Maxim, Carpino, DING, } \\
\text { Kaleske }\end{array}$ & Snap, Tapsi, Maxim, Carpino & Snap, Tapsi \\
\hline Bike sharing & Bidood & - & - \\
\hline Delivery of products & Alo-Peyk, Snap Box, Snap-Motori & Alo-Peyk, Snap Box & Alo-Peyk \\
\hline Online map/public transportation guide & Waze, Raya, Tehran-Bus & Waze, Raya, Tehran-Bus & Raya \\
\hline \multicolumn{4}{|c|}{ Traveling } \\
\hline Online platform for traveling & $\begin{array}{c}\text { Ali-Baba, Sepehr-360, Snap Trip, Charter, } \\
\text { Dalahoo, Hotel Online, Iran Hotel, Mr } \\
\text { Blit, Ticket Aid }\end{array}$ & $\begin{array}{l}\text { Ali-Baba, Sepehr-360, Snap Trip, Charter, } \\
\text { Dalahoo, Iran Hotel, Ticket Aid }\end{array}$ & Ali-Baba \\
\hline $\begin{array}{l}\text { Online platform for booking private } \\
\text { houses and rooms }\end{array}$ & Ja ba Ma, Mosem, Shab, Villa Jar & Ja ba Ma & - \\
\hline \multicolumn{4}{|c|}{ Spending free time } \\
\hline Offering cultural tickets & $\begin{array}{c}\text { Takhfifan, Net Barg, Cinema Ticket, Iran } \\
\text { Concert, Torob }\end{array}$ & $\begin{array}{c}\text { Takhfifan, Net Barg, Cinema Ticket, Iran } \\
\text { Concert }\end{array}$ & Takhfifan, Net Barg, Cinema Ticket \\
\hline Film sharing & Filimo & Filimo & - \\
\hline Game cafés & Café Fekr & Café Fekr & Café Fekr \\
\hline City guides & Piade, Dunro & Piade, Dunro & Piade \\
\hline Introducing books, art tutorials & Honari, Fidibo & Honari & - \\
\hline \multicolumn{4}{|c|}{ Health and beauty } \\
\hline Beauty services & Achareh & Achareh & - \\
\hline Online consultation for medical issues & Azmoon Hamrah, Hospital & Azmoon Hamrah, Hospital & - \\
\hline Online shopping & High Land, Rozha, Safir & High Land, Rozha, Safir & - \\
\hline \multicolumn{4}{|c|}{ Home care services } \\
\hline $\begin{array}{l}\text { Home care facilities/repairing, cleaning, } \\
\text { babysitting, etc. }\end{array}$ & Achar, Ostad Kar & Achar, Ostad Kar & - \\
\hline
\end{tabular}


Table A3. Cont.

\begin{tabular}{|c|c|c|c|}
\hline $\begin{array}{c}\text { Areas of Consumption and General } \\
\text { Description of SISC }\end{array}$ & \multicolumn{3}{|c|}{ SISC (Name of Initiatives) That Interviewee ... } \\
\hline Car repair, auditing & Alo Batri, Alo check & Alo Batri, Alo check & - \\
\hline \multicolumn{4}{|c|}{ Gifting } \\
\hline Flower services & Gol-e-Man, VIP & Gol-e-Man, VIP & - \\
\hline Online jewelry selling & Kia, Saatchi & Kia, Saatchi & - \\
\hline \multicolumn{4}{|c|}{ Secondhand platforms } \\
\hline Online platforms for reselling goods & Divar, Sheypoor & Divar, Sheypoor & Divar, Sheypoor \\
\hline \multicolumn{4}{|c|}{ Online shopping } \\
\hline Online shopping platforms & Diji Kala, Pinket, Basalam & Diji Kala, Pinket, Basalam & Diji Kala \\
\hline \multicolumn{4}{|c|}{ Transaction apps } \\
\hline Online banking & Ap. Iva, Roobika & Ap. Iva, Roobika & Ap \\
\hline Online payment for taxis & Tooman & - & - \\
\hline \multicolumn{4}{|c|}{ Co-working spaces } \\
\hline Co-working space & Work Space & Work Space & - \\
\hline \multicolumn{4}{|c|}{ Waste collection } \\
\hline Collecting recyclable garbage & Zist app & Zist app & - \\
\hline
\end{tabular}




\section{References}

1. Tracey, P.; Stott, N. Social innovation: A window on alternative ways of organizing and innovating. Innovation 2017, 19, 51-60. [CrossRef]

2. Godin, B.; Vinck, D. Critical Studies of Innovation. Alternative Approaches to the Pro-Innovation Bias; Godin, B., Vinck, D., Eds.; Edward Elgar Publishing: Cheltenham, UK, 2017.

3. Grimm, R.; Fox, C.; Baines, S.; Albertson, K. Social innovation, an answer to contemporary societal challenges? Locating the concept in theory and practice. Innov. Eur. J. Soc. Sci. Res. 2013, 26, 436-455. [CrossRef]

4. Borzaga, C.; Bodini, R. What to Make of Social Innovation? Towards a Framework for Policy Development. Soc. Policy Soc. 2014, 13, 411-421. [CrossRef]

5. Howaldt, J.; Schwarz, M. Social Innovation-Social Challenges and Future Research Fields. In Enabling Innovation; Jeschke, S., Isenhardt, I., Hees, F., Trantow, S., Eds.; Springer: Berlin/Heidelberg, Germany, 2011.

6. Jaeger-Erben, M.; Rückert-John, J.; Schäfer, M. Sustainable consumption through social innovation: A typology of innovations for sustainable consumption practices. J. Clean. Prod. 2015, 108, 784-798. [CrossRef]

7. Klein, J.-L. Introduction: Social innovation at the crossroads between science, economy and society. In The International Handbook on Social Innovation; Moulaert, F., MacCallum, D., Mehmood, A., Hamdouch, A., Eds.; Edward Elgar Publishing: Cheltenham, UK, 2013; pp. 9-12.

8. Boyko, C.; Clune, S.; Cooper, R.; Coulton, C.; Dunn, N.; Pollastri, S.; Leach, J.; Bouch, C.; Cavada, M.; De Laurentiis, V.; et al. How Sharing Can Contribute to More Sustainable Cities. Sustainability 2017, 9, 701. [CrossRef]

9. Botsman, R.; Rogers, R. What's Mine Is Yours. The Rise of Collaborative Consumption, 1st ed.; Harper Business: New York, NY, USA, 2010.

10. Karimi, A. Tehran Ranks among World's Most Polluted Cities. 2019. Available online: https: //kayhanlife.com/news/kayhan/tehran-ranks-among-worlds-most-polluted-cities/\#: \{\{:text=Tehran \%

20Air\%20Quality\%20Control\%20Company \T1\textquoterights, the\%20world\%20on\%20November\%2029 (accessed on 6 July 2020).

11. Javan. Iran's Rank for Traffic Wasted Time. 2017. Available online: https://www.javanonline.ir/fa/news/865067 (accessed on 6 July 2020).

12. Ayob, N.; Teadale, S.; Fagan, K. How Social Innovation 'Came to Be': Tracing the Evolution of a Contested Concept. J. Soc. Policy 2016, 45, 635-653. [CrossRef]

13. Ziegler, R. Social innovation as a collaborative concept. Innov. Eur. J. Soc. Sci. Res. 2017, 30, $388-405$. [CrossRef]

14. Schrader, U. Consumer acceptance of Eco-efficient services: A German perspective. Greener Manag. Int. 1999, 25, 105-121.

15. Belk, R. You are what you can access: Sharing and collaborative consumption online. J. Bus. Res. 2014, 67, 1595-1600. [CrossRef]

16. Mont, O. Institutionalisation of sustainable consumption patterns based on shared use. Ecol. Econ. 2004, 50, 135-153. [CrossRef]

17. Manzini, E.; Vezzoli, C.; Clark, G. Product-Service Systems. Using an Existing Concept as a New Approach to Sustainability. J. Des. Res. 2001, 1, 27-40. [CrossRef]

18. Phills, J.A.; Deiglmeier, K.; Miller, D.T. Rediscovering Social Innovation. Stanf. Soc. Innov. Rev. 2008, 6, $34-43$.

19. Mumford, M.D. Social Innovation: Ten Cases from Benjamin Franklin. Creat. Res. J. 2002, 14, $253-266$. [CrossRef]

20. Louise, P. This Is European Social Innovation. 2010. Available online: https://youngfoundation.org/wp-content/ uploads/2012/10/This-is-European-Social-Innovation.pdf (accessed on 6 August 2020).

21. Correa, J.C.; Garzón, W.; Brooker, P.; Sakarkar, G.; Carranza, S.A.; Yunado, L.; Rincón, A. Evaluation of collaborative consumption of food delivery services through web mining techniques. J. Retail. Consum. Serv. 2019, 46, 45-50. [CrossRef]

22. Diedrich, A.; Upham, P.; Levidow, L.; van den Hove, S. Framing environmental sustainability challenges for research and innovation in European policy agendas. Environ. Sci. Policy 2011, 14, 935-939. [CrossRef]

23. Rennings, K. Redefining innovation-Eco-innovation research and the contribution from ecological economics. Ecol. Econ. 2000, 32, 319-332. [CrossRef] 
24. Seyfang, G.; Smith, A. Grassroots innovations for sustainable development: Towards a new research and policy agenda. Environ. Politics 2007, 16, 584-603. [CrossRef]

25. Martin, C.J.; Upham, P. Grassroots social innovation and the mobilisation of values in collaborative consumption: A conceptual model. J. Clean. Prod. 2016, 134, 204-213. [CrossRef]

26. Rückert-John, J. Soziale Innovation und Nachhaltigkeit; Springer: Wiesbaden, Germany, 2013.

27. Firnkorn, J.; Müller, M. What will be the environmental effects of new free-floating car-sharing systems? The case of car2go in Ulm. Ecol. Econ. 2011, 70, 1519-1528. [CrossRef]

28. Nijland, H.; van Meerkerk, J. Mobility and environmental impacts of car sharing in the Netherlands. Environ. Innov. Soc. Transit. 2017, 23, 84-91. [CrossRef]

29. WRAP. Valuing Our Clothes. The True Cost of How We Design, Use and Dispose of Clothing in the UK. 2012. Available online: http://www.wrap.org.uk/sites/files/wrap/VoC\%20FINAL $\% 20$ online $\% 202012 \% 2007 \%$ 2011.pdf (accessed on 31 May 2020).

30. Briceno, T.; Peters, G.; Solli, C.; Hertwich, E. Using Life Cycle Approaches to Evaluate Sustainable Consumption Programs. Car-Sharing. 2004. Available online: https:/ntnuopen.ntnu.no/ntnu-xmlui/bitstream/handle/11250/ 242569/121813_FULLTEXT01.pdf?sequence=1\&isAllowed=y (accessed on 6 July 2020).

31. Melo, J.; Braz, J.d.O.B. Banco Palmas on Its 15th Anniversery. Resisting and Innovating; A9 Editora: São Paulo, Brazil, 2013.

32. Schor, J. Debating the Sharing Economy. 2014. Available online: https://greattransition.org/publication/ debating-the-sharing-economy (accessed on 6 July 2020).

33. Frenken, K. Political economies and environmental futures for the sharing economy. Philos. Trans. A Math. Phys. Eng. Sci. 2017, 375, 20160367. [CrossRef] [PubMed]

34. Santarius, T. Investigating meso-economic rebound effects: Production-side effects and feedback loops between the micro and macro level. J. Clean. Prod. 2015, 134, 406-413. [CrossRef]

35. Frenken, K.; Schor, J. Putting the sharing economy into perspective. Environ. Innov. Soc. Transit. 2017, 23, 3-10. [CrossRef]

36. Santarius, T. Green Growth Unravelled. How Rebound Effects Baffle Sustainability Targets when the Economy Keeps Growing. 2012. Available online: https:/greengrowthknowledge.org/sites/default/files/ downloads/resource/GG_Unravelled_HBF_and_WI.pdf (accessed on 6 July 2020).

37. Sorrell, S. The Rebound Effect: An Assessment of the Evidence for Economy-Wide Energy Savings from Improved Energy Efficiency. 2007. Available online: File://Users/samirairan/Downloads/TheReboundEffect_ AnAssessmentoftheEvidenceforEconomy-wideEnergySavingsfromImprovedEnergyEfficiency.pdf (accessed on 15 August 2020).

38. Druckman, A.; Chitnis, M.; Sorrell, S.; Jackson, T. Missing carbon reductions? Exploring rebound and backfire effects in UK households. Energy Policy 2011, 39, 3572-3581. [CrossRef]

39. Liedtke, C.; Baedeker, C.; Hasselkuß, M.; Rohn, H.; Grinewitschus, V. User-integrated innovation in Sustainable LivingLabs: An experimental infrastructure for researching and developing sustainable product service systems. J. Clean. Prod. 2015, 97, 106-116. [CrossRef]

40. Fischer, D.; Barth, M. Key Competencies for and beyond Sustainable Consumption an Educational Contribution to the Debate. Gaia Ecol. Perspect. Sci. Soc. 2014, 23, 193-200. [CrossRef]

41. Siebenhüner, B. Kann die Politik es richten? Konsument(inn)en alspolitische Akteure. Gaia Ecol. Perspect. Sci. Soc. 2011, 20, 14-16.

42. Hawkins, D.I.; Mothersbaugh, D.L. Consumer Behavior. Building Marketing Strategy, 13th ed.; McGraw-Hill Education: New York, NY, USA, 2016.

43. The World Bank. Urban Population (\% of Total Population). 2018. Available online: https://data.worldbank. org/indicator/SP.URB.TOTL.IN.ZS?locations=IR (accessed on 18 August 2020).

44. Atash, F. The deterioration of urban environments in developing countries: Mitigating the air pollution crisis in Tehran, Iran. Cities 2007, 24, 399-409. [CrossRef]

45. The World Bank. GINI Index (World Bank Estimate). 2017. Available online: https://data.worldbank.org/ indicator/SI.POV.GINI?locations=IR (accessed on 18 August 2020).

46. Yousefi, S.; Farahani, I. Spatial inequality in Tehran, a structural explanation. Urban Res. Pract. 2019, 1-22. [CrossRef]

47. Bahaee, M.S. Characteristics of Iranian Entrepreneurs. Int. J. Commer. Manag. 1995, 5, 62-72. [CrossRef] 
48. Salamzadeh, A.; Kesim, H.K. Startup Companies: Life Cycle and Challenges. In Proceedings of the 4th International Conference on Employment, Education and Entrepreneurship (EEE), Belgrade, Serbia, 14-16 October 2015.

49. Salamzadeh, A.; Kawamorita Kesim, H. The enterprising communities and startup ecosystem in Iran. J. Enterprising Comm 2017, 11, 456-479. [CrossRef]

50. Elahian, Z.; Akramolhmolook, L.; Haghshenas, F. Efficiency Indicators of State Environmental Agencies of Guarantee the Achievement of Environmental Sustainability. Hum. Environ. 2011, 8, 37-50.

51. Schäfer, M.; Dantas de Figueiredo, M.; Iran, S.; Jaeger-Erben, M.; E Silva, M.; Lazaro, J.C.; Meißner, M. Imitation, adaptation, or local emergency?-A cross-country comparison of social innovation for sustainable consumption in Brazil, Germany, and Iran. J. Clean. Prod. 2020. under review.

52. Fink, A. Conducting Research Literature Reviews: From the Internet to Paper, 2nd ed.; SAGE Publications: Thousand Oaks, CA, USA, 2005; ISBN 1452259496.

53. Grabs, J.; Langen, N.; Maschkowski, G.; Schäpke, N. Understanding role models for change: A multilevel analysis of success factors of grassroots initiatives for sustainable consumption. J. Clean. Prod. 2016, 134, 98-111. [CrossRef]

54. Becker-Leifhold, C.; Iran, S. Collaborative fashion consumption-Drivers, barriers and future pathways. J. Fash. Mark. Manag. Int. J. 2018, 22, 189-208. [CrossRef]

55. Tukker, A.; Charter, M.; Vezzoli, C.; Stø, E.; Munch Andersen, M. (Eds.) Perspectives on Radical Changes to Sustainable Consumption and Production; Greenleaf Publishing Limited: Sheffield, UK, 2008.

56. Mangiaracina, R.; Marchet, G.; Perotti, S.; Tumino, A. A review of the environmental implications of B2C e-commerce: A logistics perspective. Int. J. Phys. Distrib. Logist. Manag. 2015, 45, 565-591. [CrossRef]

57. Van Loon, P.; Deketele, L.; Dewaele, J.; McKinnon, A.; Rutherford, C. A comparative analysis of carbon emissions from online retailing of fast moving consumer goods. J. Clean. Prod. 2015, 106, 478-486. [CrossRef]

58. Lange, S.; Santarius, T. Smarte Grüne Welt? Digitalisierung Zwischen Überwachung, Konsum und Nachhaltigkeit; Oekom Verlag: München, Germany, 2018.

59. Felländer, A.; Ingram, C.; Teigland, R. The Sharing Economy-Embracing Change with Caution. 2015. Available online: https://www.semanticscholar.org/paper/THE-SHARING-ECONOMY-EMBRACINGCHANGE-WITH-CAUTION-Fell\%C3\%A4nder-Ingram/4740d0c80c6a4a623f5d73d8a1a30d5896bbc628 (accessed on 9 September 2020).

60. Aloisi, A. Commoditized workers: Case study research on labor law issues arising from a set of on.demand/gig economy platforms. Comp. Labor Law Policy J. 2016, 37, 653-690.

61. Herring, H.; Sorrell, S. Energy Efficiency and Sustainable Consumption; Palgrave Macmillan UK: London, UK, 2009.

62. Wageih, M.A.; Attia, M.A.; Zoheiry, A.H. Patterns of Social Innovations in the Middle East \& Northern Africa. In Atlas of Social Innovation New Practices for a Better Future; Howaldt, J., Kaletka, C., Schröder, A., Zirngiebl, M., Eds.; Sozialforschungsstelle, TU Dortmund University: Dortmund, Germany, 2018; pp. 143-145. 